\title{
Ideologija in strukturno nasilje
}

\begin{abstract}
V nasprotju z običajnim, znanim, nenadnim in posamičnim nasiljem je strukturno nasilje težje opazno, ker ga pogosto - tako akterji kot žrtve - reducirajo na nesistemske in sporadične dogodke. Mehanizmi redukcije (razlogov, posledic) so pri strukturnem nasilju podobni kot pri ideološkem mišljenju, kar je obravnavano v prvem delu tega članka. Druga dva dela prispevka sta empirična. Namenjena sta analizi ideoloških redukcij na področju socialne politike v Sloveniji, ki proizvaja značilne učinke strukturnega nasilja. Pri tem so tarče ne zgolj marginalizirane skupine (čeprav so najbolj prizadete), pač pa tudi kultura celotne družbe v pomenu lastnosti, povzetih v (romantični) sintagmi »slovenski narodni značaj «. Evropska primerjava pokaže, da je slovenski narodni značaj najbolj problematičen v sklopu vrednot glede odnosa do sebe in do oblasti. Ko ta lastnost (kulture) sovpade z nestrpnostjo do drugih, z avtoritarno vlado, s prevladujočimi radikalnimi stališči do spreminjanja družbe in z negativnimi trendi v socialni politiki, dobimo eksplozivno mešanico. Ključne besede: socialna politika, narodni značaj, fašizem, nacionalsocializem, civilna družba.
\end{abstract} Dr. Srečo Dragoš je docent na Fakulteti za socialno delo. Kontakt: sreco.dragos@fsd.uni-lj.si.

\section{Ideology and structural violence}

Unlike ordinary, known, sudden and individual violence, structural violence is more difficult to notice because it is often - by both actors and victims - reduced to unsystematic and sporadic events. The mechanisms of reduction (of causes, consequences) in structural violence are similar to those in ideological thinking, which is discussed in the first part of this article. The other two parts of the paper are empirical. They are intended for the analysis of ideological reductions in the field of social policy in Slovenia, producing the typical effects of structural violence. The target is not just marginalized groups (although they are the most affected), but also the culture of the whole society in terms of the characteristics summarized in the (romantic) expression »Slovenian national character «. The European comparison shows that the Slovene national character is the most problematic in terms of values regarding the attitude towards oneself and in relation to the authorities. When this trait (of culture) coincides with intolerance of others, with authoritarian government, with prevailing radical views on changing society, and with negative trends in social policy, we get an explosive mix.

Key words: social policy, national character, fascism, National Socialism, civil society.

Srečo Dragoš, PhD, is na Assistant Professor at the Faculty of Social Work, University of Ljubljana. Contact: sreco.dragos@fsd.uni-lj.si.

\section{Uvod}

Strukturno nasilje je ožji pojem od ideologije. Čeprav je druga možna brez prvega, pa ne velja obratno. Brez ideologije ni možno izvajati strukturnega nasilja v sodobnih družbah, saj mu ideologija daje videz legitimnosti. Ker sta si oba pojava najbolj podobna $v$ mehanizmih selekcije in redukcije realnosti, na katero referirata, hkrati pa sta tudi težko prepoznavna, je problemu redukcije namenjen prvi razdelek tega članka. Selekcija je izbiranje oz. odbiranje tistih vidikov (iz) kompleksne realnosti, ki ustrezajo interesu akterja; z redukcijo pa se realnost poenostavi $\mathrm{v}$ pomenu ponovne rekonstrukcije na podlagi selekcioniranih elementov, torej brez drugih, ki so bili s selekcijo izločeni.

Preostala razdelka sta namenjena empiriji.V drugem je prikazana (ideološka) redukcija na področju socialne politike. V zadnjem razdelku pa opozorim 
na škodljive posledice takšnih redukcij. Te ne prizadenejo samo marginaliziranih skupin, čeprav so njihova začetna tarča, pač pa škodijo vsej nacionalni kulturi, saj usodno vplivajo na tiste osebnostne lastnosti državljank in državljanov, ki jih povzemamo v (romantični) sintagmi »slovenski narodni značaj«.

\section{Redukcija}

Skupna značilnost tako ideologije kot strukturnega nasilja je redukcija. Pri strukturnem nasilju - ki pomeni, najkrajše rečeno, nasilje struktur - gre za redukcijo na treh ravneh: $v$ načinu prisile, v posledicah in njihovi pojavnosti (vidnosti). $S$ tem se ustvari napačen videz, da so akterji neosebni, da so posledice nedoločljive (zaradi razpršenosti), zanemarljive ali celo neobstoječe. V resnici drži nasprotno. Strukturno nasilje ne razbremenjuje akterjev osebne odgovornosti. Opozarjanje na strukturo ne prekvalificira nasilja v impersonalen pojav, pač pa gre za poudarek, da izvori nasilja niso zgolj v posameznikih, pač pa tudi v strukturah, ${ }^{1}$ saj te pomembno vplivajo na položaje in dejavnosti tako izvajalcev kot tudi žrtev.

Ne pozabimo na najbolj množično, brutalno in mednarodno odmevno strukturno nasilje v Sloveniji, sproženo z ustanovitvijo slovenske države, to je primer »izbrisanih«: čeprav sta osebno odgovorna tako občinski uradnik kot socialna delavka, ki uporabniku storitev na občini ali centru za socialno delo uničita dokumente, takšnega nasilja ne moremo ustrezno kvalificirati, dokler ne upoštevamo institucionalnega ozadja, v katerem se je zgodilo.

Ker je verjetno, da se iz tega primera nismo naučili ničesar, je treba vedno znova poudarjati, da je upoštevanje konteksta nujno potrebno za vpogled v problem, nikakor pa ne zmanjšuje individualne odgovornosti. Poanta je v pomenu problema - ta je v primerih strukturnega nasilja tako velik, da ni rešljiv zgolj z zamenjavo posameznikov. ${ }^{2}$ Največja težava pri tem je, da se z redukcijo posledic in njihove vidnosti strukturno nasilje dodatno minimalizira.

Prvo konkretizacijo takšnega mehanizma redukcije najdemo pri literarnem in okoljskem teoretiku Robu Nixonu (2011), ki je za ta namen skoval termin "počasno nasilje (slow violence); prvo sociološko uporabo omenjenega izraza pa najdemo pri Tadu Skotnickem (2019, str. 300):

Počasno nasilje se nanaša na izčrpavajoče trpljenje, ki se razvija nespektakularno. Je a) razpršeno v času in prostoru, b) nesorazmerno trpijo razlaščeni ali marginalizirani ljudje, c) težko ga je zaznati in si ga vizualno predstavljati.

1 Te strukture so lahko interakcijske (razmerja med statusi in vlogami znotraj socialnih skupin ter med njimi), organizacijske ( $v$ tem primeru govorimo o institucionalnem nasilju) in širše družbene (tj. na ravni družbe kot najširšega sistema, npr. rasizem, neenakost). Normativni izvori nasilja v teh strukturah so lahko formalni ali neformalni.

2 Najnovejši primer strukturnega nasilja v Sloveniji (tokrat znotraj represivnega dela državnega aparata) je direktiva notranjega ministra Aleša Hojsa direktorju policije, naj izvede revizijo nekaterih že končanih postopkov, ki jih je obravnaval Nacionalni preiskovalni urad. Gre za revizijo primerov, ki se niso končali tako, kot si želi stranka SDS, ki je trenutno na oblasti. Čeprav gre za značilen primer strukturnega nasilja - nelegalen poseg izvršne oblasti v Nacionalni preiskovalni urad - tisti, ki se bodo uklonili takšnim pritiskom, niso brez odgovornosti! Pravna stroka in policijski sindikat izrecno opozarjata, »da se policistke in policisti zaradi izvajanja spornih usmeritev in navodil lahko spravijo v pravdni ali kazenski postopek« (Felc, 2020). 
Skotnicki je koncept »počasnega nasilja « uporabil pri analizi dveh primerov aktivističnega boja za pravice. Prvi je v zvezi z največjo industrijsko katastrofo na svetu, ki se je zgodila z eksplozijo plina v indijskem Bhopalu (1984), v drugem, starejšem primeru pa gre za ameriško gibanje za pravice potrošnikov z začetka 20. stoletja, ki je opozarjalo na socialne probleme in izkoriščanje delovne sile. Pri tem je Skotnicki ugotovil, da je bila ključna za uspeh obeh vrst - sicer zelo različnih in nepovezanih - socialnih gibanj njuna taktika, saj je bila $\mathrm{v}$ obeh primerih pozornost akterjev osredotočena na razkrinkavanje "počasnega nasilja «, ki se ga je dotlej prikrivalo z mehanizmom redukcije (po dimenzijah a, b in c v prejšnjem navedku). To pomeni, da nevzdržne delovne razmere, revščina, izkoriščanje (ameriških delavcev) ali pa sevanje, zastrupitev s svincem in drugimi toksičnimi plini (Bhopal) učinkujejo počasi in hkrati na vseh ravneh, od mikro- do makroravni in od organskih do najširših družbenih sistemov. Skotnicki (2019, str. 306) trdi:

Analogno se prostorski registri počasnega nasilja gibljejo od celičnega do nadnacionalnega.

Ker so ti obsežni »registri« težje zaznavni, je bilo najprej treba razbiti predsodek o tem, da je vse, kar je »nespektakularno «, tudi nepomembno. ${ }^{3}$

$\mathrm{V}$ nasprotju z običajnim, znanim, nenadnim in (največkrat) individualnim nasiljem je nasilje struktur težje opazno, ker se ga reducira na nesistemske in sporadične dogodke. ${ }^{4}$ Takšno početje je olajšano zaradi teh značilnosti: ker strukturno nasilje ni omejeno zgolj na posameznike, ker je bolj dolgoročno, ker deluje hkrati na zelo različnih ravneh, ker njegove žrtve nikakor niso vsi »člani« nasilnih struktur (pač pa najbolj marginalizirani in najmanj vidni), ker izvora takšnega nasilja ni mogoče locirati v eni točki ${ }^{5}$ in zato tudi ni vidno na prvi pogled. ${ }^{6}$ Te značilnosti na videz zmanjšujejo pomen strukturnega nasilja, lahko celo tako zelo, da

3 Enako velja tudi za percepcijo aktualne pandemije, čeprav gre za navidezni paradoks. Če primerjamo številke, pandemija nikakor ni »spektakelska « (Skotnicki), a jo razumemo drugače. Pandemija covida-19 se nam zdi daleč najhujši problem zato, ker je izbruh te okužbe nov, nenaden, zelo viden (vsakodnevno preštevamo okužene) in ker neposredno vpliva na ekonomijo ter vsakodnevne navade ljudi tudi v bogatih družbah. Hkrati pa podcenjujemo druge oblike množične smrtnosti, čeprav zahtevajo veliko več smrti - a ker so brez »spektakelske « funkcije in z daljšo zgodovino, smo se nanje že navadili. Do zdaj je zaradi covida-19 življenje izgubilo 0,01 odstotka svetovnega prebivalstva, podhranjenih pa je 830 milijonov ljudi ali 11 odstotkov svetovnega prebivalstva. Kaj je ena stotinka odstotka proti enajstim odstotkom? Vsako leto zaradi lakote umre devet milijonov ljudi, »kar je več kot zaradi aidsa, malarije in tuberkuloze skupaj. Po podatkih organizacije The World Counts vsakih deset sekund en otrok umre od lakote« (Vladić, 2020).

»Večina subjektov sprejema svojo ideološko samokonstitucijo kot 'resnično' ali 'naravno' in se zato le redko spoprijema z represivnim državnim aparatom, ki je zasnovan tako, da kaznuje vsakogar, ki zavrača prevladujočo ideologijo « (Farheen, 2020, str. 5). Zato se hegemonija manj opira na klasične, trde aparate državne represije (npr. policijo) in bolj na druge, mehkejše, zlasti na socialno delo, socialno politiko, izobraževanje ipd., ki niso nič manj ideološki.

5 Na to okoliščino opozarja tudi Foucault s termini, kot so: biopolitika (Foucault, 2000a), bio-oblast in mikro-oblast (Foucault, 2000b, str. 148, 150).

6 »Strukturno nasilje je posredna vrsta nasilništva. Ta vrsta nasilja je vgrajena v družbene strukture in je manj vidna od fizičnega ali psihičnega nasilja; strukturno ali posredno nasilje je težko prepoznavno, ker izhaja iz celotne mreže struktur [...] Strukturno nasilje je načrten izraz političnih ali drugih struktur, da bi škodovale drugim posameznikom in koristile družbenopolitičnemu in gospodarskemu okolju. (Gimba Mavalla in Osah, 2016, str. 192) 
ljudje učinke podcenjujejo ali celo zanikajo (ne pozabimo: kljub 25.671 žrtvam »izbrisa « je v slovenski javnosti in celo znotraj pravosodja ter med pravnimi eksperti kar osem let vztrajalo prepričanje, da je problem »izbrisanih« izmišljen). ${ }^{7}$

Da se minimaliziranje pojava sploh lahko zgodi, pa je potrebna ideologija - in tudi ta temelji na redukcijah.

Poleg običajnih, nujnih in neškodljivih redukcij, ki jih pri spoprijemanju s kompleksnostjo vsi uporabljamo že na ravni vsakdanjega življenjskega sveta, ${ }^{8}$ je za ideološko mišljenje značilna še dodatna, posebna vrsta redukcionizma, ki realnost reducira glede na interese in moč. To sta prva opozorila že pred desetletji Berger in Luckmann v (takrat) najbolj citiranem družboslovnem delu, Družbena konstrukcija realnosti. ${ }^{9}$ Iz njunega poudarka lahko izpeljemo natančnejšo definicijo:

ideologija je vsak interesno pogojen konstrukt realnosti, ki se z uporabo družbene moči uveljavlja na račun drugih in drugačnih (konkurenčnih) konstruktov.

Iz tega sledi, da ideologija v razmerju do realnosti pomeni dvakratno redukcijo, saj gre za redukcijo redukcije. ${ }^{10} \mathrm{~V}$ tem pogledu je Althusserjeva revizija Marxa pravilna, ko trdi, da »je ideologija brez zgodovine« (Althusser, 1971, str. 6).

V nadaljevanju si poglejmo dve nevarni obliki ideoloških redukcij, negacijo in fašizacijo. Obe se v Sloveniji razraščata še bolj kot v večini evropskih držav.

\section{Negacija}

Negacija je korak naprej od ignorance. Primer ideološke ignorance na socialnem področju je izjava nekdanjega finančnega ministra Dušana Mramorja v zvezi z revščino, ki jo je minimaliziral z besedami, češ da je pri nas "prikazana zelo populistično « (ker imamo še vedno evropsko podpovprečen delež revnih).$^{11}$ Ko pomen problema zmanjšamo s sklicevanjem na druga okolja, kjer je problem večji, postane takšna redukcija pripravna podlaga za korak naprej v zanikanje problema. Primer takšne negacije pa je izjava aktualnega ministra za delo in družino, ki pravi, da je »Slovenija na področju revščine in socialne izključenosti ena najbolj učinkovitih v boju s tema dvema pojavoma« (Cigler Kralj, 2020).

Gre za čas od izbrisa, ki ga je leta 1992 nelegalno izvedlo Ministrstvo za notranje zadeve, pa do leta 1998, ko je slovensko Ustavno sodišče odločilo, da je bil izbris neustaven. Desne politične stranke, ki se sklicujejo na krščanske vrednote - na čelu s stranko SDS - problema še danes ne priznavajo.

8 Paradigmatski primer takšne redukcije kompleksnosti je obvladovanje prostora, da se v njem lažje znajdemo; o tem je prvi pisal Alfred Schutz (1976) v eseju Tujec (za analizo takšne redukcije glej: Dragoš in Leskošek, 2003, str. 15-20).

9 »Ko se posebna definicija realnosti pritrdi na konkretni interes moči, jo lahko imenujemo ideologija « (Berger in Luckmann, 1988, str. 114). Enako razumevanje ideologije je opazno tudi v najnovejših besedilih, npr. pri F. Adamu (»politika vidi samo tisto, kar ji njeni interesi in ideologija omogočajo, da vidi. Kar je izven tega vidnega polja, ostaja netematizirano «; Adam, 2020, str. 160).

10 Podrobneje o različnih vrstah ideoloških redukcij in konstruktov $v$ zvezi z družbeno neenakostjo glej: Dragoš in Leskošek, 2003, str. 9-40.

11 Izjava v intervjuju z Mramorjem (2015). Kritiko citiranega stališča glej v Dragoš (2015). 
Tudi v tej izjavi je uporabljen enak »argument« kot v prejšnji - sklicevanje na druga okolja. Res je, da je delež revnega in socialno izključenega prebivalstva v Sloveniji nekoliko manjši od povprečja drugih evropskih držav - a to nikakor ne pomeni, da je naša država »ena najbolj učinkovitih v boju s tema dvema pojavoma«. Res je prav nasprotno: smo ena od najslabših držav, kot je razvidno iz preglednice 1.

Preglednica 1: Deprivacija na najpomembnejših področjih življenja - primerjava Slovenije s povprečjem EU, Združenim kraljestvom, Češko in Grčijo (\%).

\begin{tabular}{|c|c|c|c|c|c|c|c|}
\hline \multicolumn{2}{|c|}{ PODROČJE DEPRIVACIJE } & $\begin{array}{c}\text { EU } 28 \\
\text { (Euro 19) }\end{array}$ & UK & CZE & GRC & SVN & $\begin{array}{l}\text { Razlika } \\
\text { (\%) } \\
\text { SVN/EU } \\
28 \\
\end{array}$ \\
\hline \multirow{2}{*}{\multicolumn{2}{|c|}{$\begin{array}{l}\text { 1. Stanovanjska deprivacija }{ }^{12} \\
\text { 2. Socialna zaščita na področju nastanitve (\% BDP) }{ }^{13}\end{array}$}} & $\begin{array}{c}13,9 \\
(14,1)\end{array}$ & 17,6 & 7,7 & 12,9 & 22,7 & $+63,3$ \\
\hline & & $\begin{array}{c}0,54 \\
(0,42) \\
\end{array}$ & 1,17 & 0,22 & 0,02 & 0,02 & $-96,3$ \\
\hline \multirow{10}{*}{$\begin{array}{l}\text { 3. Zdravstvena } \\
\text { deprivacija } \\
(=\text { slabo zdravje })^{14}\end{array}$} & 3.1. vsi $(16+)$ & 8,8 & 8,9 & 11,8 & 10,4 & 10,0 & $+13,6$ \\
\hline & $16-24$ & 1,5 & 3,0 & 0,5 & 0,8 & 2,1 & $+40,0$ \\
\hline & $25-34$ & 2,2 & 3,8 & 2,2 & 2,0 & 3,4 & $+54,5$ \\
\hline & $35-44$ & 3,9 & 7,0 & 4,3 & 3,5 & 3,2 & $-17,9$ \\
\hline & $45-54$ & 7,3 & 9,2 & 9,6 & 5,2 & 8,0 & $+9,6$ \\
\hline & $55-64$ & 11,6 & 12,2 & 14,7 & 8,7 & 13,6 & $+17,2$ \\
\hline & $65-74$ & 13,6 & 11,1 & 17,3 & 17,2 & 18,1 & $+33,1$ \\
\hline & $75-84$ & 23,2 & 15,3 & 34,2 & 35,1 & 32,2 & $+33,1$ \\
\hline & $85+$ & 34,7 & 17,4 & 49,1 & 59,5 & 35,2 & $+1,4$ \\
\hline & $\begin{array}{l}\text { 3.2. umrli zaradi covida-19v } \\
\text { domovih za stare }\end{array}$ & \multicolumn{6}{|c|}{$\begin{array}{l}\text { Zaradi diskriminacije starejših ima Slovenija » ne samo evropski } \\
\text { temveč tudi svetovni rekord po deležu umrlih v domovih za } \\
\text { stare « (Keber, 2020) }{ }^{15}\end{array}$} \\
\hline \multirow{4}{*}{$\begin{array}{l}\text { Deprivacija } \\
\text { javnega } \\
\text { zdravstva }^{16}\end{array}$} & 3.3. število ${ }^{17}$ bolniških postelj & 5,3 & 2,9 & 6,8 & 4,8 & 4,6 & $-13,2$ \\
\hline & 3.4. število zdravnikov & 3,41 & 2,81 & 3,71 & 4,38 & 2,54 & $-25,5$ \\
\hline & 3.5. zasebni izdatki za zdravstvo ${ }^{18}$ & 26,61 & 16,86 & 15,46 & 38,34 & 28,27 & $+6,2$ \\
\hline & $\begin{array}{l}\text { 3.6. financiranje dolgotrajne } \\
\text { oskrbe (\% BDP) }{ }^{19}\end{array}$ & 1,4 & l & / & l & 0,9 & $-35,7$ \\
\hline
\end{tabular}

12 Gre za odstotni delež prebivalstva, ki živi v stanovanju z vsaj eno od teh značilnosti: puščajoča streha, vlažne stene, tla ali temelji, gniloba v okenskih okvirjih ali tleh.

13 Podatki so za leto 2017, razen za povprečje EU, ki je iz leta 2016 (Eurostat, 2020).

14 Zdravstvena deprivacija označuje odstotni delež prebivalstva, ki izjavlja, da je njihovo zdravje slabo ali zelo slabo (podatek velja za leto 2016; Eurostat, 2018, str. 81).

15 Zaradi velikosti tega smrtonosnega problema in nujnosti njegove evalvacije - ki še ni narejena - navajam najpomembnejša besedila o tem: Keber, 2020b, 2020c, 2020d, 2020e; Jager, 2020a, 2020b; Pleterski, 2020a, 2020b; Tomc, 2020; Ferlič Žgajnar, 2020; Malovrh, 2020; Marolt Meden, 2020; Al, 2020a, 2020b, 2020c; Repovž, 2020; Ćetković, 2020; Hočevar, 2020; Siter, 2020; STA, 2020a; Košak, 2020; Bizjak, 2020; zadnji pregled kronologije zapleta in arogance Ministrstva za zdravje je objavljen v STA, $2020 \mathrm{~b}$.

16 Vir: Žlogar, 2016.

17 Število bolniških postelj in število zdravnikov na 1000 prebivalcev.

18 Gre za odstotni delež izdatkov za zdravstvo iz zasebnih virov, glede na celoto sredstev, namenjenih za zdravstvo (podatek je za 2014). 


\begin{tabular}{|c|c|c|c|c|c|c|c|c|c|}
\hline \multicolumn{4}{|c|}{ 3.7. Deležż zaposlenih v zdravstvu in socialnem delu²0 } & $\begin{array}{c}\text { OECD:21 } \\
10,1\end{array}$ & 12,3 & 6,4 & 5,4 & 6,5 & $-35,6$ \\
\hline \multirow{2}{*}{\multicolumn{2}{|c|}{$\begin{array}{l}\text { 4. Internet: uporaba } \\
\text { e-pošte } 22\end{array}$}} & \multicolumn{2}{|r|}{ vsi } & 75 & 89 & 82 & 59 & 72 & $-4,0$ \\
\hline & & \multicolumn{2}{|c|}{65 do 74} & 47 & 74 & 45 & 16 & 33 & $-29,8$ \\
\hline \multirow{2}{*}{\multicolumn{2}{|c|}{$\begin{array}{l}\text { Izdatki, } \\
\% \mathrm{BDP}^{23}\end{array}$}} & \multicolumn{2}{|c|}{ 5.1. za socialno zaščito } & $\begin{array}{c}27,9 \\
(28,9) \\
\end{array}$ & 26,3 & 18,6 & 25,2 & 22,6 & $-19,0$ \\
\hline & & \multicolumn{2}{|c|}{ 5.2. za brezposelnost } & $\begin{array}{c}1,2 \\
(1,4) \\
\end{array}$ & 0,3 & 0,5 & 0,9 & 0,5 & $-58,3$ \\
\hline \multirow{7}{*}{ 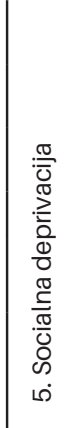 } & \multirow{3}{*}{ 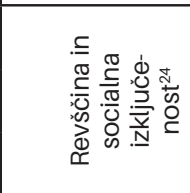 } & \multicolumn{2}{|c|}{ 5.3. samska oseba } & $\begin{array}{c}31,9 \\
(30,5)\end{array}$ & 32,8 & 30,8 & 35,0 & 43,1 & $+35,1$ \\
\hline & & \multicolumn{2}{|c|}{$\begin{array}{l}\begin{array}{l}\text { 5.4. samska ženska } \\
\text { (brez otrok) }\end{array} \\
\end{array}$} & $\begin{array}{c}32,2 \\
(30,3)\end{array}$ & 33,0 & 37,7 & 35,5 & 45,3 & $+40,7$ \\
\hline & & \multicolumn{2}{|c|}{ 5.5. samski $65+$} & $\begin{array}{c}28,3 \\
(25,5)\end{array}$ & 29,5 & 38,7 & 29,0 & 43,4 & $+53,4$ \\
\hline & \multicolumn{3}{|c|}{ 5.6. Brez soc. omrežja (\%) ${ }^{25}$} & 5 & 1 & 6 & / & 8 & $+60,0$ \\
\hline & \multicolumn{3}{|c|}{ 5.7. Stopnja tveganja revščine $(65+)^{26}$} & $\begin{array}{c}16,1 \\
(14,9)\end{array}$ & 20,4 & 14,2 & 11,6 & 18,3 & $+13,7$ \\
\hline & \multirow{2}{*}{\multicolumn{2}{|c|}{ 5.8. Vztrajanje v revščini²7 }} & od 50 do 64 & $\begin{array}{c}10,1 \\
(10,7)\end{array}$ & 7,5 & 5,9 & 11,2 & 11,8 & $+16,8$ \\
\hline & & & $65+$ & $\begin{array}{c}10,3 \\
(10,6)\end{array}$ & 8,1 & 4,6 & 7,1 & 13,8 & $+34,0$ \\
\hline & \multicolumn{3}{|c|}{ 5.9. Materialna deprivacija starejših $(65+)^{28}$} & $\begin{array}{c}11,2 \\
(10,3)\end{array}$ & 4,7 & 8,7 & 30,7 & 12,5 & $+11,6$ \\
\hline & \multirow{2}{*}{\multicolumn{2}{|c|}{ Minimalni dohodek 29}} & $\begin{array}{l}\text { 5.10. samska } \\
\text { os. brez otrok }\end{array}$ & \multirow{2}{*}{$\begin{array}{c}\text { OECD: }{ }^{30} \\
33\end{array}$} & 53 & 21 & 27 & 29 & $-12,1$ \\
\hline & & & $\begin{array}{l}\text { 5.11. par brez } \\
\text { otrok }\end{array}$ & & 46 & 14 & 28 & 31 & $-6,1$ \\
\hline
\end{tabular}

Viri: navedeni v opombah od 12 do 31.

20 »Zdravje in socialno delo sta podsistema storitvenega sektorja in sta opredeljeni kot sestavini zdravstvenih dejavnosti, zdravstvenih storitev (tudi dolgotrajne oskrboe in dejavnosti socialnega dela brez nastanitve «; podatek je odstotni delež zaposlenih glede na vse zaposlene v letu 2017 (OECD, 2019).

21 Povprečje 36 držav.

22 V odstotkih; podatek je za leto 2019 (Eurostat, 2020). Glej tudi König, Alexander in Doh (2018).

Podatki o izdatkih za socialno zaščito in brezposelnost so za leto 2017 (Eurostat, 2020).

24 Pri tveganju revščine ali socialne izključenosti gre za osebe, ki jim grozi revščina ali pa so zelo materialno prikrajšane ali živijo $v$ gospodinjstvu z zelo majhno delovno intenzivnostjo. Osebe so pri štetju upoštevane samo enkrat, tudi če so navzoče v več kategorijah (podatki so za 2018; Eurostat, 2020).

25 Vir: Filipovič Hrast in Srakar, 2015, str. 210 (pri podatku za EU gre za povprečje petnajstih evropskih držav).

26 Gre za stopnjo tveganja revščine starejših od 64 let (60 \% mediane) po socialnih transferjih, podatek je za leto 2018 (Eurostat, 2020).

27 Delež revnih, ki ostajajo pod pragom revščine (60 \% mediane) že najmanj tretje leto (podatek je za 2018; Eurostat, 2020).

28 Materialna deprivacija je opredeljena kot odstotni delež prebivalstva, ki mu na področju materialne prikrajšanosti primanjkujejo najmanj tri eksistenčne dobrine (od devetih najnujnejših). Podatki $v$ tej vrstici veljajo za kategorijo starejših od 64 let (podatki za leto 2018; Eurostat, 2020).

29 Kazalnik meri dohodek brezposelnih oseb, ki temelji na zajamčenih minimalnih prejemkih, izraženih kot odstotek mediane razpoložljivega dohodka v državi (za leto 2018; OECD, 2020). Povprečje 41 držav.

31 »Po podatkih Eurostata je bila razlika v plačilu med spoloma v Sloveniji leta 2017 osemodstotna, medtem ko je bila $v$ celotni EU v povprečju 16-odstotna. A prav $v$ Sloveniji je ta plačna vrzel $v$ letih 2010-2017 narasla najbolj v EU « (Odbor SE, 2020). Enak trend je v Sloveniji opazen celo v akademski sferi (Antič Gaber, 2018). Ob tem je treba dodati, da je problem še hujši. Navedeni podatki se nanašajo na primerjavo nacionalnih povprečij, problem z velikostjo plačne vrzeli pa je $\checkmark$ Sloveniji še večji, ko ga pogledamo od blizu in se z nacionalne ravni premaknemo na primerjavo po dejavnostih, poklicnih skupinah in delovnih mestih (Poje in Roksandić, 2013, str. 23-28). 
Če prej citirano izjavo ministra Ciglerja Kralja primerjamo s preglednico 1 , se pokaže, da gre ne zgolj za neresnično trditev (v pomenu zmote), pač pa za eksplicitno in namerno zanikanje problema. Kajti nismo najboljši - smo med najslabšimi. Kaj je negirano? Razmeroma nizka stopnja družbenih neenakosti in socialne izključenosti ter razmeroma visoka stopnja enakosti med spoloma v Sloveniji sta sicer resnična podatka, a to velja samo za nacionalno povprečje, ko se primerjamo z drugim nadnacionalnim povprečjem (EU, OECD). Sklicevanje na povprečje je ideološko takrat, ko aludira na realnost (ne pa na povprečje) z namenom, da se realnost zakriva. ${ }^{32}$ Kaj ostaja zakrito?

Najprej se prikriva odsotnost konsenza o vrednotenju tega, kar naj bi povprečje sploh dokazovalo. Še vedno se nismo uskladili, ali je majhna neenakost ali pa manjši delež revnega prebivalstva nekaj dobrega ali ni, hkrati pa so trendi v tej zvezi zelo problematični. Če obdobje pred zadnjo ekonomsko krizo (2002-2008) primerjamo s kriznimi leti (2009-2015), sodimo po merilu povečevanja dohodkovnih neenakosti med trojico najslabših evropskih držav: najbolj je neenakost povečala Hrvaška, takoj za njo Slovenija, tretja pa je Španija (Jianu, 2018, str. 126). Enako je z neenakostjo med spoloma. Kljub precej ugodnim podatkom o tem, ki so pri nas izrazito boljši od evropskega povprečja, imamo katastrofalen trend: v obdobju 2010-2017 se je plačna vrzel med spoloma v Sloveniji povečala bolj kot pa v vseh drugih državah EU (Odbor SE, 2020).

Enako je z revščino. Med 24 kazalci s socialnega in zdravstvenega področja (v preglednici 1) smo prav pri vseh slabši od evropskega povprečja. Zlasti iz zadnjega stolpca preglednice je razvidno, katera so najbolj kritična področja: stanovanjska in socialna zaščita (merjeno z deležem BDP), nekatere starostne kategorije v zvezi z zdravstveno zaščito, tudi deleži zaposlenih na tem področju, izdatki za brezposelnost, revščina in socialna izključenost samskih oseb, neopremljenost s socialnimi omrežji, razsežnost revščine starejših in povečanje plačne vrzeli med spoloma - pri teh kazalnikih zaostajamo za evropskim povprečjem od 30 do 96 odstotkov, pri drugih kazalnikih pa od 4 do 30 odstotkov. Prav tako smo tudi po skoraj vseh kazalnikih slabši od Združenega kraljestva (UK), Češke (CZE) in Grčije (GRC), ki sem jih vključil v preglednico, ker bi nas primerjava s temi državami morala še posebej skrbeti. Kajti UK je tako rekoč evropski sinonim neoliberalizma, saj se je začel prav $v$ tej državi (s premierko Thatcher in sočasno z ZDA) in v času brexita nič ne kaže, da bi popuščal. Ker se slovenska država vseskozi deklarira za socialno in nikoli za neoliberalno, je zelo neobičajno, da zaostajamo (v 19 kazalcih) za UK prav na socialnem in zdravstvenem področju. Podobno velja za Češko in Grčijo. Prva nam je bila v času osamosvojitve najbolj podobna (po omenjenih

Zakaj sklicevanje na primerjavo povprečij ni dovolj niti za odličnost niti za učinkovitost, ki nam jo eksplicitno pripisuje minister? Zaradi več razlogov (empirični so v preglednici 1), med katerimi je najbolj splošen razlog s področja logike. Ministrova izjava je napačna, ker iz primerjave naših razmer s tistimi v tujini, kjer je stanje slabše od našega, ni mogoče izpeljati trditve, da so razmere pri nas dobre. Kajti če bi se primerjali s tistimi, ki so boljši od nas - pa se ne - bi bil sklep nasproten. Isto velja tudi v primeru, če bi se primerjali z državami, ki so po različnih kazalcih v resnici najbolj primerljive s Slovenijo (npr. s Češko). Še več, zaostajamo celo za državami, ki so celo slabše od nas (glej opombo 33). 
kazalcih še malenkost slabša od nas), danes pa smo občutno slabši od Češke, in sicer v 17 kazalcih; enako velja celo za Grčijo, ki je od zadnje ekonomske krize najbolj problematična v vsej EU, ${ }^{33}$ a smo kljub temu še slabši od nje.

V opisan razvojni vzorec smo zašli zaradi odsotnosti konsistentne in avtonomne socialne politike - ta je podrejena ekonomski, ki pa je neoliberalna. Zato občasne majhne spremembe socialnih kazalcev navzgor ali navzdol niso indikator učinkov socialne politike, pač pa bolj posledica konjunkturno-recesijskih ciklov v gospodarstvu in restriktivne vloge države do »nerealnih « sektorjev. Odsotnost socialne politike na Slovenskem je dobro vidna na grafu 1.

Graf 1: Obstoječa denarna podpora je lahko neenakomerna in ni vedno natančno usmerjena v revne.

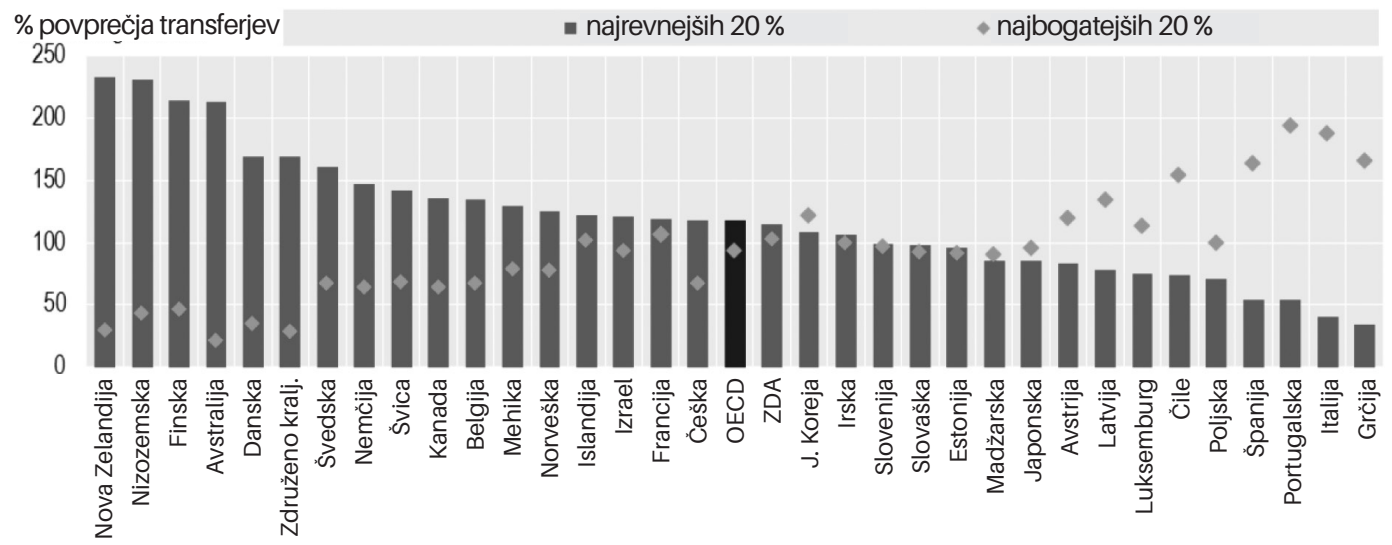

Vir: OECD, 2017, str. 1.

Za razumevanje grafa 1 naj opozorim na tri aksiome v zvezi s socialno politiko:

1. razvoj modernih demokratičnih držav, ki imajo tržno gospodarstvo, ni možen brez posebne - za socialna vprašanja specializirane - socialne politike,

2. temeljna družbena funkcija vsak(ršn)e socialne politike je državna redistribucija sredstev od zgornjih k spodnjim slojem, in sicer po netržnih merilih (politika, ki tega ne počne, ni socialna),

3. najpomembnejša razlika med socialnimi politikami je v tem, kdo in koliko ima korist od državne redistribucije - to velja tako za razlike med posameznimi koncepti socialne države (Powell, Yörük in Bargu, 2020; Ahmad, 1991) kot tudi v časovnih primerjavah znotraj iste države, ko se isti koncept različno prakticira pod različnimi oblastmi.

Kot je razvidno iz grafa 1, so znotraj kluba najbogatejših držav (OECD) velike razlike $\mathrm{v}$ socialnih politikah, ki nikakor ne sovpadajo z razvitostjo njihovih gospodarstev (merjeno z BDP na prebivalca). Za države na levi strani grafa je značilno, da s svojo socialno politiko redistribuirajo sredstva veliko bolj v

33 Grčija je gospodarsko skoraj uničena, je najbolj zadolžena in z migracijami preobremenjena članica EU, ki ob tem postaja vse bolj tudi politično in varnostno nestabilna (zaradi najnovejšega turškega militarističnega pritiska v zvezi z nafto in Ciprom). Kljub temu ostaja celo Grčija - največji bolnik v EU - boljša od Slovenije po številnih socialnih indikatorjih, takšnih je kar sedemnajst! Ti so v preglednici 1 navedeni pod številkami: 1, sledi pet starostnih kategorij znotraj indikatorja 3.1., 3.2, 3.3, 3.4, 5.1, 5.2, 5.3, 5.4, 5.5, 5.7, 5.8 in 5.12. 
korist spodnjim slojem kot pa zgornjim, kar je, kot rečeno, osnovna funkcija socialne politike (2. aksiom). Če torej primerjamo države po transferjih, ki jih prejemajo delovno sposobni posamezniki $\mathrm{v}$ skupinah $\mathrm{z}$ nizkimi in visokimi dohodki, ni presenetljivo, da se na skrajno levo stran omenjenega grafa uvrščajo skandinavske države, skupaj z Novo Zelandijo, Avstralijo in celo Združenim kraljestvom. Nasprotno velja za desno polovico grafa, kjer državna redistribucija najbolj koristi najbogatejšim 20 odstotkom prebivalstva, najmanj pa najrevnejši petini družbe. Primerjava pokaže, da je Slovenija na desni strani, torej slabša od povprečja OECD, za katerega je sicer značilno, da redistribucija še vedno malenkost bolj koristi revnim kot pa bogatim. Pri nas to ne velja več. Slovenska »socialna " politika nameni najbogatejši petini enak odstotek državnih transferjev kot najrevnejši petini prebivalstva. To pomeni, da pri nas sploh nimamo socialne politike (v pomenu prejšnjih aksiomov). Kot vidimo, so po tem merilu bolj socialne od Slovenije celo ZDA.

Kako je to mogoče? Res je, kot sem omenil že prej, da nimamo razvite avtonomne niti strokovne socialne politike, saj je ta instrumentalizirana pod ekonomsko. Kljub temu vprašanje ostaja: kako je mogoče, da je socialna politika postala transmisija ekonomske, ki je neoliberalna? ${ }^{34} \mathrm{~A}$ tudi neoliberalizem je presplošen odgovor, saj ne pojasni, kako uspeva političnim elitam, da se z njim napajajo že vse od osamosvojitve. Odgovor je v civilni družbi.

\section{Fašizacija}

Ob skorajšnji 80-letnici nastanka Osvobodilne fronte (OF) je njena četrta točka edina od sedmih, ki je še aktualna in neuresničena. $V$ njej je bilo predvideno, da se bo z aktivizacijo množic preoblikoval »slovenski narodni značaj « ${ }^{35}$ tako, da se bo uveljavil »nov lik aktivnega slovenstva«. Potrebo po tej točki najbolje dokazujejo besede italijanskega diplomata T. C. Rappa, ki je tik pred ustanovitvijo OF slovenski narodni značaj opisal takole:

Slovenska politika je, naravno, odraz značaja naroda. Marljivi, vztrajni in počasnega mišljenja so Slovenci dobri podrejeni uslužbenci, iz njihovih vrst pa izide le malo voditeljev. (Nećak, 2008, str. 175)

Ker se od navedene diagnoze iz leta 1938 značajsko nismo spremenili, se je mogoče strinjati z opozorilom, da ostaja četrta točka OF še vedno »najzanimivejša in najbolj aktualna«, saj je s svojo programsko zahtevo "glavno sporočilo za danes« (Repe, 2020).

34 To kaže tudi zaporedje pojmov, omenjenih v nazivu ministrstva, ki naj bi bilo pristojno za socialno politiko: Ministrstvo za delo, družino, socialne zadeve in enake možnosti. Na prvem mestu je delo, ki ne sodi v socialno, pač pa v ekonomsko politiko, saj je tu mišljena regulacija trga delovne sile; na drugem mestu je družina, ki je izvzeta iz socialne politike (zaradi redukcije na natalitetno politiko; več v Dragoš, 2017) - šele za tem sledijo socialne zadeve, ki zgolj asociirajo na nekakšno socialno politiko, si pa podrejajo tudi profesijo socialnega dela (čeprav to ni socialna politika). Gre za enako zmoto, kot če bi imeli, denimo, sociološko profesijo za del politike z izgovorom, da se obe področji ukvarjata z družbo, ali pa bi uvrstili profesijo strojništva pod kmetijstvo, češ, saj tudi v kmetijstvu uporabljajo stroje. Simptomatično je, da je od tretjeuvrščenih socialnih zadev manj pomembno samo še področje enakih možnosti, ki je ministrstvu dodano nazadnje.

Zaradi razširjenosti tudi sam uporabljam izraz » narodni značaj «, čeprav gre za pleonazem. Ustreznejši izraz za to sintagmo je »kultura «. 
Namesto iskanja razlogov za to, da je OF v tej točki ostala neuspešna, ${ }^{36}$ se usmerimo k vprašanju, kakšno je stanje danes in kje so rešitve.

Pomemben element strukturnega nasilja ni le pritisk avtoritarnih vlad in političnih strank od zgoraj, nasilje je lahko tudi proizvod civilne družbe ${ }^{37} \mathrm{Ko}$ postane večinsko javno mnenje dojemljivo za širjenje nestrpnosti in vrednostno združljivo z izključevalnimi politikami, se pojavi nestrpnost od spodaj, ki je ne moremo več reducirati zgolj na proizvod oblasti. Z nestrpnostjo civilne družbe dobi ta pojav novo, avtonomno podlago in zagon. To pomeni, da nestrpnosti ne moremo več pojasnjevati zgolj z lastnostjo semena, pač pa tudi s kakovostjo humusa, v katerega je bilo potaknjeno. To interakcijo med »sejalci« od zgoraj in humusom civilne družbe so avtorji frankfurtske šole povezali $\mathrm{z}$ avtoritarnim sindromom:

Medtem ko se razmere spreminjajo, se jim nekateri posamezniki prilagajajo veliko hitreje kot drugi. V razmerah, ko bi se povečala antidemokratična propaganda, bi jo nekateri takoj sprejeli in ponotranjili, drugi bi ji sledili zaradi vtisa, ker ji pač »vsi verjamejo«, nekateri pa bi jo zavrnili. Z drugimi besedami, posamezniki se razlikujejo po svoji dovzetnosti za antidemokratično propagando kot tudi po pripravljenosti za izražanje antidemokratičnih teženj. Zato se zdi nujno, da preučujemo ideologijo že na tej »stopnji dovzetnosti«, da bi ocenili potenciale fašizma v konkretni družbi. (Adorno, Frenkel-Brunswik, Levinson in Sanford, 1950, str. 4).

Čeprav je v desetletjih po objavi navedenega dela merjenje »fašističnega značaja « postalo predmet številnih preverjanj, kritik in revizij ${ }^{38}$ - predvsem v zvezi

36 Verjetno sta bila najpomembnejša razloga dva: ker je prenova narodnega značaja znotraj enostrankarskega sistema nevaren projekt; in drugič, ker prav nobena od točk OF - niti v vseh njenih različicah - ni vključevala nikakršne omembe socialnega vprašanja ali zmanjšanja družbenih neenakosti. Ti cilji niso samodejno uresničljivi z osvoboditvijo in sklicevanjem na »človečnost « (tu je šlo za napačno predpostavko o socialnem avtomatizmu, ki se ji še danes nismo odpovedali; več o tem v Dragoš, 2005: 67-68, 77).

37 Eden prvih, ki je (sicer arhaičen) pojem civilne družbe očistil idealizacije in ga s tem usposobil za analizo sodobnih družb, je John Keane, v slovenskem prostoru pa Tomaž Mastnak. Oba sta vodilna predstavnika tiste smeri v politologiji, ki sodi, da je mogoče »jezik civilne družbe enako dobro vnašati tudi v takšne različne politične pojave, kot so zaton države blaginje, vzpon neoliberalizma in rast družbenih gibanj « (Keane, 2000, str. 7). Stališča in vrednote državljank in državljanov, ki so nam dostopne z javnomnenjskimi meritvami (na katere se sklicujem v nadaljevanju), so eden od ključnih in razmeroma avtonomnih elementov civilne družbe, ki je seveda ne moremo reducirati na podaljšek državne sfere, sicer se znajdemo v totalitarizmu. Po Keanu je ključna razlika med državo in civilno družbo v tem, da prva ustvarja » kompleksno mrežo političnih institucij (ki zajemajo vojaška, pravna, administrativna, produkcijska in kulturna telesa države) «, pojem civilne družbe pa se nanaša na sfero »družbenih (zasebno lastniških, tržno usmerjenih, prostovoljno vodenih ali na prijateljstvu utemeljenih) dejavnosti, ki jih država priznava in jamči. «Prav to razlikovanje je po Keanovem mnenju »hkrati zelo uporabno tudi za osvetlitev razlogov, zakaj pojema priljubljenost keynesianske države blaginje « (Keane, 1990, str. 53). Pomemben del odgovora na to vprašanje sta neoliberalizem in njegov vpliv na vrednostna stališča posameznikov (kot jih prikazujem v preglednici 2) in povezava takšnih stališč s problemi, ki jih obravnavam v nadaljevanju članka.

Ena od novejših je Feldmanova (2003). Avtor prepozna glavni razlog za nastanek avtoritarnega sindroma $v$ » konfliktnosti med konformizmom in željo po povečanju osebne avtonomije. « $V$ tej razpetosti pri rangiranju ene in druge vrednote je, kot pravi avtor, ključna » percepcija grožnje «. Predsodki in nestrpnost so (po tem modelu) » rezultat kombinacije pri vrednotenju socialne konformnosti in zaznanih nevarnosti za socialno kohezijo « (Feldman, 2003, str. 66-67). 
z empiričnim zajemanjem podatkov, uporabljenimi merskimi lestvicami kot tudi teoretsko (pretirana psihologistična oz. freudistična razlaga) - ostajajo temeljni poudarki frankfurtske šole nesporni. Tu omenjam tri postulate, ki so aktualni za našo temo, in sicer:

- interakcionistični: avtorji izhajajo iz teze, »da korenite spremembe družbenih razmer in institucij neposredno vplivajo na tipe osebnosti, ki se razvijejo v takšni družbi« (Adorno, Frenkel-Brunswik, Levinson in Sanford, 1950, str. 6),

- sociološki: avtoritarni sindrom je, kot so ugotovili avtorji že pred 70 leti, zlasti »v Evropi močno razširjen v nižjih srednjih slojih. V evropskih družbah ga lahko pričakujemo med ljudmi, katerih dejanski status se razlikuje od statusa, za katerega si prizadevajo« (ibid., str. 759-760),

- stigmatizacijski: »Omeniti je treba še eno značilnost sindroma ,avtoritarnosti'. To je psihološki ekvivalent obravnavane ideologije ,ni-milosti-za-revne' [...] Identifikacija ,avtoritarnega' značaja z močjo sovpada z zavračanjem vsega, kar je ,spodaj'. Tudi takrat, ko je očitno, da je deklasiran status proizvod družbenih razmer in depresivnega položaja skupine, se uporabi preobrat, kjer se to spremeni v nekakšno zasluženo kazen « (ibid., str. 761-762).

V nadaljevanju poglejmo, kakšna je nestrpnost od spodaj - ta humus avtoritarnosti - v Sloveniji. V preglednici 2 povzemam nekatere ključne vrednote v slovenskem in evropskem javnem mnenju, ki so povezane z avtoritarnostjo. Številke od ena do devet (v drugi vrstici preglednice) označujejo stališča, ki so bila respondentom ponujena za opredeljevanje na večstopenjski lestvici. $\mathrm{V}$ legendi podajam formulacijo teh stališč, v preglednici pa so odstotki pritrdilnih odgovorov po posameznih državah.

\section{Legenda k preglednici 2}

Odnos do sebe:

1. Pomembno je pokazati svoje sposobnosti in biti občudovan.

2. Pomembno je, da me ljudje spoštujejo.

3. Pomembno je, da se pravilno vedemo.

4. Pomembno je biti ponižen in skromen, da ne vzbudimo pozornosti.

5. Pomembno je izvesti, kar mi je naročeno, in upoštevati pravila.

6. Pomembno je upoštevati tradicije in običaje.

Odnos do oblasti:

7. Pomembno je, da je vlada močna in zagotavlja varnost.

8. Pomembno je, da so ljudje obravnavani enako in imajo enake možnosti.

9. Nezaupanje $\mathrm{v}$ politike. 
Preglednica 2: Sestavine avtoritarnega sindroma v evropskih državah (v \%).

\begin{tabular}{|c|c|c|c|c|c|c|c|c|c|c|}
\hline \multirow{2}{*}{\multicolumn{2}{|c|}{ Pomembno je .... }} & \multicolumn{6}{|c|}{ Odnos do sebe } & \multicolumn{3}{|c|}{ Odnos do oblasti } \\
\hline & & 1. & 2. & 3. & 4. & 5. & 6. & 7. & 8. & 9. \\
\hline \multicolumn{2}{|l|}{ Avstrija } & 14,6 & 9,1 & 27,5 & 22,1 & 13,7 & 19,1 & 5,9 & 49,7 & 34,5 \\
\hline \multicolumn{2}{|l|}{ Belgija } & 13,5 & 11,4 & 29,6 & 44,0 & 16,2 & 27,5 & 15,0 & 57,6 & 35,2 \\
\hline \multicolumn{2}{|l|}{ Bolgarija } & 3,5 & 6,2 & 16,7 & 22,3 & 16,7 & 26,2 & 4,2 & 26,7 & 50,2 \\
\hline \multicolumn{2}{|l|}{ Švica } & 9,3 & 16,6 & 22,5 & 41,9 & 10,6 & 20,2 & 13,1 & 54,2 & 23,9 \\
\hline \multicolumn{2}{|l|}{ Ciper } & 9,4 & 12,4 & 36,0 & 50,6 & 15,7 & 35,3 & 19,7 & 69,0 & 55,9 \\
\hline \multicolumn{2}{|l|}{ Češka } & 4,5 & 10,3 & 13,8 & 20,8 & 17,5 & 17,1 & 16,1 & 32,3 & 37,1 \\
\hline \multicolumn{2}{|l|}{ Nemčija } & 6,1 & 8,3 & 16,2 & 36,4 & 12,8 & 20,0 & 26,1 & 57,1 & 37,7 \\
\hline \multicolumn{2}{|l|}{ Estonija } & 5,0 & 4,0 & 26,5 & 28,2 & 14,6 & 17,3 & 23,9 & 32,6 & 43,0 \\
\hline \multicolumn{2}{|l|}{ Finska } & 3,5 & 3,2 & 17,9 & 25,7 & 22,9 & 16,4 & 20,1 & 57,4 & 22,6 \\
\hline \multicolumn{2}{|l|}{ Francija } & 4,3 & 5,0 & 20,6 & 42,5 & 6,6 & 13,1 & 10,2 & 54,6 & 47,5 \\
\hline \multicolumn{2}{|c|}{ Združeno kraljestvo } & 7,7 & 5,5 & 22,2 & 38,6 & 12,2 & 15,3 & 19,6 & 50,1 & 42,4 \\
\hline \multicolumn{2}{|l|}{ Madžarska } & 7,9 & 9,2 & 20,7 & 25,4 & 11,2 & 15,7 & 14,6 & 33,8 & 27,7 \\
\hline \multicolumn{2}{|l|}{ Irska } & 6,4 & 7,2 & 20,5 & 41,2 & 14,0 & 17,7 & 11,4 & 50,6 & 34,0 \\
\hline \multicolumn{2}{|l|}{ Italija } & 3,2 & 9,4 & 20,2 & 35,6 & 20,0 & 20,4 & 3,7 & 35,0 & 46,5 \\
\hline \multicolumn{2}{|l|}{ Nizozemska } & 9,4 & 8,3 & 18,5 & 25,4 & 15,9 & 22,8 & 18,3 & 67,1 & 17,1 \\
\hline \multicolumn{2}{|l|}{ Norveška } & 4,5 & 6,8 & 32,3 & 16,0 & 27,1 & 19,8 & 19,2 & 49,9 & 23,1 \\
\hline \multicolumn{2}{|l|}{ Poljska } & 7,9 & 14,0 & 21,3 & 24,7 & 25,6 & 24,5 & 13,4 & 45,4 & 47,9 \\
\hline \multicolumn{2}{|l|}{ Srbija } & 7,6 & 10,4 & 31,9 & 38,8 & 23,4 & 30,3 & 11,5 & 54,3 & 26,3 \\
\hline \multicolumn{2}{|l|}{ Slovenija } & 25,4 & 22,7 & 50,4 & 73,5 & 26,1 & 32,3 & 33,4 & 73,5 & 54,0 \\
\hline \multirow{2}{*}{$\begin{array}{l}\text { POVPREČJE } \\
\text { (brez Slo.) }\end{array}$} & Vse države & 7,1 & 8,7 & 23,1 & 32,2 & 16,5 & 21,0 & 14,8 & 48,7 & 36,3 \\
\hline & Ex-socialist. (6) & 6,1 & 9,0 & 21,8 & 26,7 & 18,2 & 20,2 & 13,9 & 37,5 & 38,7 \\
\hline
\end{tabular}

Vir: ESS (2018).

Med devetnajstimi državami, prikazanimi v preglednici 1, najbolj izstopa po vseh merilih testiranja samo ena država - Slovenija. Pri prvih šestih stališčih, ki testirajo odnos do samega sebe, je slovenski delež pritrdilnih odgovorov daleč največji med vsemi državami: pod številkami 1, 2, 3 in 4 smo na prvem mestu, pri 5. in 6. stališču pa na drugem. Med vsemi evropskimi državami smo torej prav Slovenci najbolj narcistični (1 in 2), konformistični $(3,5$ in 6) in podredljivi oz. pohlevni (4). Pri teh osebnostnih preferencah tako zelo odstopamo od evropskega povprečja in celo od povprečja nekdanjih socialističnih držav - s katerimi smo sicer po drugih merilih in polstoletni zgodovini najbolj primerljivi - da bi moralo biti sram vsakega, ki ima še vsaj kanček državljanskega ponosa. Kajti ne gre zgolj za dejstvo, da smo najbolj narcistični, konformistični in pohlevni. Nevarnost je hujša. Ko te lastnosti sovpadejo, kažejo na rigiden tip osebnosti, kakršnega so Adorno in drugi označili za avtoritarnega in (proto) fašističnega. Zato je ustrezneje lastnosti tega tipa zapisati z vezajem: v evropskem prostoru smo Slovenci najbolj narcistično-konformistično-pohlevni. ${ }^{40}$

39 Pri prvih osmih trditvah sta združena prva dva odgovora (merjena s šeststopenjsko lestvico), ki pomenita največjo stopnjo strinjanja; pri deveti trditvi pa je združenih prvih pet odgovorov (merjenih na 11-stopenjski lestvici), ki izražajo največjo stopnjo averzije do politikov.

40 Najbolj zjedreno formulacijo te diagnoze je (sklicujoč se na Adorna) podal Vlado Miheljak, ko pravi, da je za avtoritarno osebnost značilna »biciklistična narava: ali se podrejaš, ko si šibkejši, ali si podrejaš, ko si močnejši « (Miheljak, 2020, str. 6). 
Tega problema se, sodeč po številu znanstvenih objav o omenjeni temi, ne zavedamo niti znotraj slovenske sociologije. V skladu s klasičnim slovenskim kulturnim sindromom ${ }^{41}$ ni naključje, da je prav umetnost edina, ki pri nas obravnava probleme, ki bi jih morala reševati politika in raziskati znanost. Najprodornejšo kritično refleksijo avtoritarne osebnosti, značilne za Slovence, najdemo $\mathrm{v}$ gledališču in literaturi (namesto $\mathrm{v}$ politiki in znanosti). Prav to, kar kažejo številke iz prejšnje preglednice, povzame pesnik Boris A. Novak (2020) z izrazom »pekel slovenstva«:

Pekel slovenstva brez kulture [...], brez dialoga z drugimi, brez razgledov in srca, brez elementarne človeške spodobnosti, brez kakršnekoli vsebine razen praznega blebetanja, kako ponosni smo na to, da smo Slovenci. Da smo le skupaj, v istem krogu pekla. In dovolj visoko, da lahko serjemo na glave Romom in Bosancem, izbrisanim in beguncem, šibkejšim in drugačnim. Tak je slovenski krog pekla.

Ko se vrednotenje samega sebe $\mathrm{v}$ pomenu avtoritarnih vrednot združi še $\mathrm{z}$ odnosom do oblasti, dobimo eksplozivno mešanico. Iz stališč pod številkami 7, 8 in 9 (v preglednici 2) je razvidno, da smo Slovenci tudi visoko nad evropskim povprečjem - celo nad povprečjem nekdanjih socialističnih držav - po vrednotenju močne oblasti (7), po vrednotenju egalitarizma (8) in po nezaupanju v politiko (9). Tudi tu smo prvi v Evropi, le pri 9. stališču smo drugi. Iz tega izhaja radikalizacija stališč glede spreminjanja slovenske družbe, ki jo potrjujejo vse raziskave slovenskega javnega mnenja (v preglednici 3).

Preglednica 3: Radikalizacija stališč o spreminjanju slovenske družbe.

\begin{tabular}{|c|c|c|c|c|c|c|}
\hline $\begin{array}{c}\text { Spodaj so zapisani trije značilni } \\
\text { pogledi na družbo, v kateri živi- } \\
\text { mo. Kateri izmed njih je najbliže } \\
\text { vašemu mnenju? }\end{array}$ & 1995 & $\begin{array}{c}1999-2007 \\
\text { (povprečje) }\end{array}$ & 2008 & 2013 & 2018 & $\begin{array}{c}\text { Razlika } \\
1995-2018 \\
\text { (v\%) }\end{array}$ \\
\hline $\begin{array}{c}\text { a) Našo družbo, tako kot je sedaj, } \\
\text { je treba braniti pred vsakršnim } \\
\text { spreminjanjem.42 }\end{array}$ & 21,9 & 10,9 & 8,7 & 2,8 & 2,3 & $-89,5$ \\
\hline $\begin{array}{c}\text { b) Našo družbo je treba postopo- } \\
\text { ma izboljšati z reformami. }\end{array}$ & 62,7 & 65,5 & 72,0 & 33,9 & 53,5 & $-14,7$ \\
\hline $\begin{array}{c}\text { c) Z odločno }{ }^{43} \text { akcijo je treba ko- } \\
\text { renito spremeniti celoten način } \\
\text { delovanja naše družbe. }\end{array}$ & 6,5 & 12,4 & 12,7 & 57,4 & 40,0 & $+515,4$ \\
\hline
\end{tabular}

Vir: Toš, 2018, str. 1012-1013.

41 Slovenski kulturni sindrom je - najkrajše rečeno - » nacionalno prizadevanje na kulturno-umetniški način « (Rupel, 1987, str. 46) v zvezi s problemi in vprašanji, ki bi jih morala tematizirati politika, pa je zaradi njene nezadostnosti to vlogo prevzela umetnost, zlasti literatura. Prvi je problem nezadostne razvitosti sektorjev oz. nacionalne delitve dela na Slovenskem tematiziral Dušan Pirjevec, ko je leta 1969 s sintagmo » prešernovska struktura " Označil nekompletiranost narodne zavesti v pomenu, da je poezija »edina samozavest slovenskega naroda « (Pirjevec, 1978, str. 56). Prvo podrobnejšo elaboracijo tega problema v pomenu » kulturnega sindroma « pa je opravil Dimitrij Rupel $(1976,1987)$. Poanta: očitno imamo z omenjenim sindromom nacionalne nerazvitosti opraviti še danes, trideset let po osamosvojitvi.

42 Pri tej trditvi je bila v meritvah do leta 2003 namesto besede »spreminjanjem « uporabljena beseda » prevratom «.

43 Pri tej trditvi je bila v meritvah do leta 2003 namesto sintagme » $z$ odločno akcijo « uporabljena sintagma »z revolucionarno akcijo $\ll$. 
Slovensko javno mnenje se je v zadnjih dveh desetletjih radikaliziralo glede vprašanja, kako spremeniti družbo. Konservativna (a) in reformistična opcija (b) izgubljata podporo, radikalna (c) pa se je okrepila kar za 515 odstotkov glede na leto 1995. Je to dobro ali slabo? Ali ni to afirmacija aktivnega državljanstva v pomenu priporočil EU ali celo afirmacija kritičnega državljanstva, ki ga imajo nekateri kar za vrlino in moralno dolžnost (Teršek, 2013)? Ne, nič od tega. Verjetneje gre za avtoritarni refleks, ki se radikalizira.

\section{Sklep}

Ideologija in strukturno nasilje imata dve glavni značilnosti. Prva so dominantna razmerja družbene moči med vpletenimi akterji, druga skupna značilnost pa je redukcionističen odnos do realnosti. Pri ideologiji je pogled na realnost prirejen interesom (s selekcijo in redukcijo), pri strukturnem nasilju pa je realnost reducirana $\mathrm{v}$ treh dimenzijah: $\mathrm{v}$ načinu izvajanja nasilja, $\mathrm{v}$ njegovih posledicah (razpršenost) in vidnosti. Zato je strukturno nasilje težje zaznavno od posamičnega, npr. individualnega. In enako je z ideologijo, njene konstrukte je težje razkrinkati kot pa druge načine potvarjanja realnosti, npr. običajno laž.

Socialna politika na Slovenskem je eno od pomembnih področij strukturnega nasilja, ki se vzdržuje z ignoranco in negacijo družbenih dejstev (v Durkheimovem pomenu). ${ }^{44}$ Po številnih pokazateljih s socialnega področja in po velikosti najbolj ogroženih kategorij prebivalstva Slovenija ne sodi med najboljše države, pač pa med najslabše v Evropi. A ti problemi v zvezi z napačno socialno politiko in prevladujočo neoliberalno paradigmo ne prizadenejo le družbenih margin (čeprav njih najprej in najbolj), pač pa tudi celotno družbo. Če avtoritarni pogled (preglednica 2) povežemo z egalitarizmom, na katerega se vežeta okrepljeni nacionalizem in povečana nestrpnost do tujcev (Dragoš, 2018), vse to pa združimo z radikalnim nagnjenjem do spreminjanja družbe, dobimo nacionalsocializem, ne pa aktivnega državljanstva v pomenu dejavnega humanizma.

Bistvo Durkheimove sintagme »družbena dejstva « je v pozivu, da »je treba družbena dejstva obravnavati kot stvari. «S tem je sociologijo - takratno novo znanstveno disciplino - skušal preusmeriti od Comtovega in Spencerjevega načina razmišljanja (od njiju je Durkheim tudi prevzel omenjeno sintagmo), ki sta o družbi zgolj teoretizirala na podlagi idej. Ideje res lahko spozna(va)mo introspektivno, pravi Durkheim, a ker so družbena dejstva nekaj več od idej, » ne morejo biti zgolj miselna dejavnost «, torej za njihovo spoznavanje potrebujemo » podatke zunaj uma « (Ritzer, 1992, str. 78). Durkheim je družbena dejstva razvrstil najprej na materialna in nematerialna, potem pa jih je razlikoval še navznoter na posamezne podvrste. Materialna je delil na tri podvrste, nematerialna pa na štiri. Pojav revščine ter z njo prizadetih skupin in slojev bi po Durkheimu sodil v tretjo vrsto materialnih dejstev, ki jo je imenoval »morfološka komponenta družbe «, socialna politika pa bi sodila v drugo vrsto materialnih dejstev, kamor se uvrščajo »strukturne komponente družbe « (Ritzer, 1992, str. 80). 


\section{Viri}

Adam, F. (2020). Med meritokracijo in populizmom. Ljubljana: Irsa.

Adorno, W. T., Frenkel-Brunswik, E., Levinson, D., \& Sanford, N. (1950). The authoritarian personality: studies in prejudice series, Volume 1. New York: Harper \& Brothers. Pridobljeno 15. 5. $2020 \mathrm{~s} \mathrm{http://www.ajcarchives.org/main.php?Groupingld=6490}$

Ahmad, E. (1991). Social security and the poor. The World Bank Research Observer, 6(1), 105-127.

Al (2020a). Gre za pravico do zdravja in življenja ljudi v domovih za starejše. Amnesty International Slovenije: Mladina, 30. 7. 2020. Pridobljeno 30. 7. 2020 s https://www.mladina. si/200304/amnesty-international-gre-za-pravico-do-zdravja-in-zivljenja-ljudi-v-domovih-za-starejse/

Al (2020b). Socialnovarstveni zavodi nimajo zmogljivosti za izvajanje con. Amnesty International Slovenije, 3. 8. 2020. Pridobljeno 12. 8. 2020 s https://www.amnesty.si/socialni-zavodi-pripravljenost-na-cone

Al (2020c). Ravnanje oblasti ob koronavirusu. Amnesty International Slovenije, 17(2), 6-7.

Antić Gaber, M. (2018). Akademske institucije v Sloveniji in (ne)enakost spolov. Javnost: The Public, 25(1), 81-96.

Althusser, L. (1971). Ideology and ideological state apparatuses. V Lenin and philosophy and other essays. New York: New Left Books, 5-34. Pridobljeno 26. 8. 2020 s https:// www.academia.edu/2940218/_Ideology_and_Ideological_State_Apparatuses_Notes_ towards_an_Investigation_1970_?email_work_card=title

Berger, P. L., \& Luckmann, T. (1988). Družbena konstrukcija realnosti. Ljubljana: Cankarjeva založba.

Bizjak, J. (2020). Intervju (intervjuvar: V. Jager). Mladina, 36, 4. september 2020, str. 35-39.

Cigler Kralj, J. (2020). Intervju z Janezom Ciglerjem Kraljem, ministrom za delo, družino, socialne zadeve in enake možnosti (intervjuvar: Vilko Kolbl). Socialna zbornica Slovenije, 30. 4. 2020. Pridobljeno 10. 5. 2020 s https://media.wix.com/ugd/304490_6d11c03e06294eca987aaa1edcec782b.pdf

Ćetković F. (2020). Javno pismo. Mladina, 31, 31. julij 2020, str. 5.

Dragoš, S., \& Leskošek, V. (2003). Družbena neenakost in socialni kapital. Ljubljana: Mirovni inštitut.

Dragoš, S. (2005). Multikulturalizem - rešitev ali problem? V V. Leskošek (ur.), Mi in oni - nestrpnost na Slovenskem. Ljubljana: Mirovni inštitut, str. 41-80.

Dragoš, S. (2015). Populistično? Mladina, 35, 28. 8. 2015, str. 17-22.

Dragoš, S. (2017). Erozija družinske politike. Socialno delo, 56(3), 157-178.

Dragoš, S. (2018). Refugees and Slovenian authoritarianism. V I. Ž. Žagar, N. Kogovšek Šalamon, \& M. Lukšič Hacin (ur.), The disaster of European refugee policy: perspectives from the "Balkan Route". UK: Cambridge Scholars Publishing, str. 197-224.

ESS (2018). European Social Survey, Round 9 Data. Norway: Norwegian Centre for Research Data - Data Archive and distributor of ESS data for ESS ERIC. Pridobljeno 15. 5. $2020 \mathrm{~s}$ http://www.europeansocialsurvey.org/data/conditions_of_use.html

Eurostat (2018). Living conditions in Europe - 2018 edition. Luxembourg: Publications Office of the European Union.

Eurostat (2020). Main tables. Pridobljeno 25. 4. 2020 s https://ec.europa.eu/eurostat/web/ europe-2020-indicators/europe-2020-strategy/main-tables

Farheen, S. (2020). Ideology and ideological state apparatuses. Academia.edu., str. 5. Pridobljeno 12. 8. 2020 s https://www.academia.edu/38167676//deology_and_Ideological_State_Apparatuses

Felc, M. (2020). Direktor policije bo sledil navodilu ministra. Delo, 13. 8. 2020. pridobljeno 13. 8. 2020 s https://www.delo.si/novice/slovenija/direktor-policije-bo-sledil-navodilu-ministra-339611.html 
Feldman, S. (2003). Enforcing social conformity: a theory of authoritarianism. Political Psychology 24(1), 41-74.

Ferlič Žgajnar, B. (2020). Navedbe, da so bili oskrbovanci DSO zapostavljeni, so neresnične. Delo, 10. junij 2020. Pridobljeno 14. 7. 2020 s https://www.delo.si/novice/slovenija/navedbe-da-so-bili-oskrbovanci-dso-med-epidemijo-zapostavljeni-so-neresnicne-in-zlonamerne-317909.html

Filipovič Hrast, M., \& Srakar, A. (2015). Socialna izključenost: primerjava Slovenije z evropskimi državami. V B. Majcen (ur.), Značilnosti starejšega prebivalstva v Sloveniji - prvi rezultati raziskave SHAR, str. 206-214. Ljubljana: Inštitut za ekonomska raziskovanja.

Foucault, M. (2000a). The birth of biopolitics. V P. Rabinow (ur.), Ethics, essential works of Foucault 1954-1984 (Vol. 1). London: Penguin Books, str. 67-71.

Foucault, M. (2000b). Zgodovina seksualnosti, 1. del. Ljubljana: ŠKUC.

Gimba Mavalla, A., \& Osah, G. (2016). Conflict transformation: a preferred model in responding to structural violent conflict in Sub-Saharan Africa. Jos Journal of Conflict Management and Peace Studies (1), 189-203.

Hočevar, B. (2020). Problematiko izpostavljajo ljudje, ki jo živijo, politiki pa se menjajo. Sobotna priloga Dela, 1. avgust 2020, str. 3.

Jager, V. (2020a). Dušenje kritičnih glasov. Mladina, št. 24, 12. 6. 2020, str. 24-27.

Jager, V. (2020b). So življenja nekaterih vredna manj? Mladina, št. 30, 24. 7. 2020, str. 34.

Jianu, I. (2018). The impact of government health and education expenditure on income inequality in European Union. Theoretical and Applied Economics. Special Issue, str. 121-134.

Keane, J. (1990). Despotizem in demokracija. Ljubljana: Univerzitetna konferenca ZSMS. Keane, J. (2000). Civilna družba. Ljubljana: Znanstveno in publicistično središče.

Keber, D. (2020a). V smrtni pasti. Dnevnik, Objektiv, 23. 5. 2020. Pridobljeno 20. 6. 2020 s https://www.dnevnik.si/1042930055/mnenja/kolumne/v-smrtni-pasti-

Keber, D. (2020b). Kaj pa, če res ne vedo, kaj delajo? Mladina, 23, 5. 6. 2020, str. 44-45.

Keber, D. (2020c). Politika, stroka in etika. Sobotna priloga Dela, 6. 6. 2020, str. 15.

Keber, D. (2020d). Odziv na intervju dr. Marka Noča. Sobotna priloga Dela, 18. 7. 2020, str. 30.

Keber, D. (2020e). Dlaka v enem od dveh gnilih jajc. Mladina (34), 21. 8. 2020, str. 22.

König, R., Alexander, S. \& Doh, M. (2018). Internet use among older Europeans: an analysis based on SHARE data. Universal Access in the Information Society, 17, 621-633. Pridobljeno 3. 6. $2020 \mathrm{~s}$ https://link.springer.com/article/10.1007/s10209-018-0609-5

Košak, K. (2020). Kako so nastala sporna navodila za triažiranje starostnikov? Dnevnik, 18. 8. 2020. Pridobljeno 18. 8. 2020 s https://www.dnevnik.si/1042936650/slovenija/kako-so-nastala-sporna-navodila-za-triaziranje-starostnikov

Malovrh, P. (2020). Gantar: Dom v Hrastniku je bil neustrezen že pred epidemijo. Delo, 23.7. 2020. Pridobljeno 17. 9. 2020 s https://www.delo.si/novice/slovenija/kako-zajeziti-sirjenje-okuzb-v-domovih-za-starejse-332950.html

Marolt Meden, B. (2020). Srebrna nit sporoča: Dovolj je! Dnevnik, 30. 7. 2020. Pridobljeno 30. 7. 2020 s https://www.dnevnik.si/1042935261/mnenja/odprta-stran/srebrna-nit-sporoca-dovolj-je

Miheljak, V. (2020). 780 milijonov. Mladina (34), 21. 8. 2020, str. 6.

Mramor, D. (2015). »Če bodo vsi zahtevali višje plače in pokojnine, bom pred barikadami dejansko stal sam «. Mladina, 8. 5. 2015. Dosegljivo 14. 12. 2020 s https://www.mladina. si/166289/dusan-mramor/

Nećak, D. (2008). Kriza: svet in Slovenci od prve svetovne vojne do sredine tridesetih let. Ljubljana: Znanstvenoraziskovalni inštitut Filozofske fakultete.

Nixon, R. (2011). Slow violence and the environmentalism of the poor. Cambridge: Harvard University Press.

Novak, A. B. (2020). Krogi pekla od Srebrenice do Slovenije ali Janez Janša, ban Alpsko-Jad- 
ranske orbanovine. Dnevnik, 18. 8. 2020. Pridobljeno 19. 8. 2020 s https://www.dnevnik. si/1042936605/kultura/knjiga/krogi-pekla-od-srebrenice-do-slovenije-ali-janez-jansa-ban-alpskojadranske-orbanovine

Odbor SE (2020). Slovenija krši pravico do enakega plačila ne glede na spol. Strasbourg, 29. junija: Odbor Sveta Evrope (SE) za socialne pravice. Pridobljeno 30. 6. 2020 s https:// www.tax-fin-lex.si/Home/Novica/16991

OECD (2017). Basic income as a policy option: can it add up? OECD, maj 2017. Pridobljeno 27. 8. 2020 s https://www.oecd.org/social/Basic-Income-Policy-Option-2017.pdf

OECD (2019). Health at a glance 2019, OECD Indicators. Paris: OECD Publishing. Pridobljeno 26. 5. $2020 \mathrm{~s}$ https://doi.org/10.1787/4dd50c09-en

OECD (2020). Adequacy of minimum income benefits. OECD iLibrary. Pridobljeno 24. 5. 2020 s https://www.oecd-ilibrary.org/employment/adequacy-of-minimum-income-benefits/indicator/english_dcb819cd-en

Pirjevec, D. (1978). Vprašanje o poeziji: vprašanje naroda. Maribor: Obzorja.

Pleterski, A. (2020a). Koronavirus, zdravniški paternalizem in borba za prazne bolniške postelje. Sobotna priloga Dela, 11. julij 2020, str. 14-15.

Pleterski, A. (2020b). Pokroviteljski kopitar. Dnevnik, 22. 8. 2020. Pridobljeno 22. 8. 2020 s https://www.dnevnik.si/1042936951/mnenja/odprta-stran/pokroviteljski-kopitar

Poje, A., \& Roksandić, M. (2013). Enako plačilo za enako delo in plačna vrzel med spoloma. Ljubljana: Zveza svobodnih sindikatov Slovenije.

Powell, M., Yörük, E., \& Bargu, A. (2020). Thirty years of the three worlds of welfare capitalism: a review of reviews. Social Policy \& Administration, 54(1), 60-87.

Repe, B. (2020). Ob dnevu upora: iz naroda hlapcev smo vstopili v krog suverenih narodov (intervju). MMC RTV SLO: 27. april 2020. Pridobljeno 31. 5. 2020 s https://www.rtvslo.si/ moja-generacija/novice/ob-dnevu-upora-iz-naroda-hlapcev-smo-vstopili-v-krog-suverenih-narodov/521989

Repovž, G. (2020). Zavestna malomarnost. Mladina, 31, 31. julij 2020, str. 2.

Ritzer, G. (1992). Sociological theory. New York: McGraw-Hill, Inc.

Rupel, D. (1976). Svobodne besede (od Prešerna do Cankarja). Koper: Lipa.

Rupel, D. (1987). Besede božje in božanske. Ljubljana: Cankarjeva založba.

Schutz, A. (1976). The stranger: an essay in social psychology. V A. Schutz, Collected papers II: studies in social theory. The Hague: Martinus Nijhoff, str. 91-105.

Siter, P. (2020). Dom starejših Hrastnik: izpoved prostovoljca. Mladina, št. 32, 7. 8. 2020, str. 22-24.

Skotnicki, T. (2019). Unseen suffering: slow violence and the phenomenological structure of social problems. Theory and Society, 48, 299-323. Pridobljeno 12. 8. $2020 \mathrm{~s} \mathrm{https://link.}$ springer.com/article/10.1007/s11186-019-09343-7\#citeas

STA (2020a). Skupnost socialnih zavodov izstopila iz delovne skupine za covid-19. Tax-FinLex, 4. 8. 2020. Pridobljeno 4. 8. 2020 s https://www.tax-fin-lex.si/Home/Novica/17330

STA (2020b). Izstop Skupnosti socialnih zavodov iz delovne skupine za covid-19. Delo, 3. 8. 2020. Pridobljeno 6. 8. 2020 s https://www.delo.si/novice/slovenija/izstop-skupnosti-socialnih-zavodov-iz-delovne-skupine-za-covid-19-337070.html

Tax-Fin-Lex (2020). Različne organizacije in združenja od vlade zahtevajo pripravo zakona o dolgotrajni oskrbi. 8. 6. 2020. Pridobljeno 9. 6. 2020 s https://www.tax-fin-lex.si/Home/ Novica/16784

Teršek, A. (2013). Državljanstvo je odgovornost. Pogledi, 4 (13-14), 10. julij 2013. Pridobljeno 15. 5. 2020 s https://pogledi.delo.si/ljudje/drzavljanstvo-je-odgovornost

Tomc, G. (2020). Zdravniki odločajo o tem, kdo bo deležen zdravljenja in kdo ne. Sobotna priloga Dela, 11. julij 2020, str. 30-31.

Toš, N. (ur.) (2018). Vrednote v prehodu XII. Ljubljana: FDV, IDV, CJMMK.

Vladić, N. (2020). Zakaj virusa ne jemljemo resno. Delo, 6. 8. 2020. Pridobljeno 6. 8. $2020 \mathrm{~s}$ https://www.delo.si/mnenja/gostujoce-pero/zakaj-virusa-ne-jemljemo-resno-337754.html 
Žlogar, M. (2016). V Sloveniji na voljo vedno manj bolniških postelj. SiolNET, 18. 10. 2020. Pridobljeno 25. 4. 2020 s https://siol.net/novice/slovenija/v-sloveniji-na-voljo-vedno-manj-bolniskih-postelj-427941. 